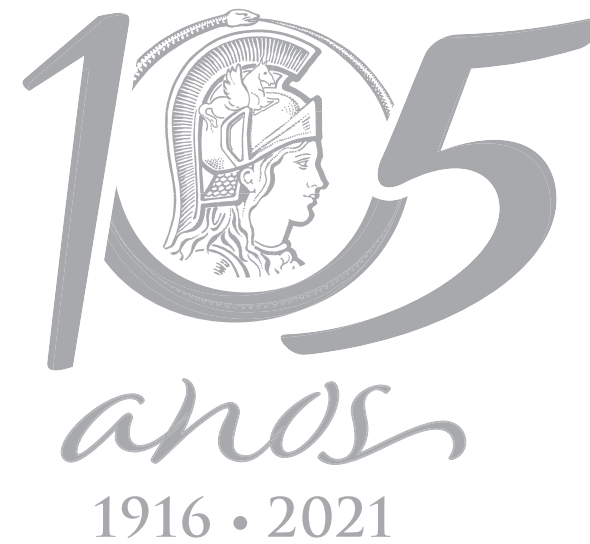

$1916 \cdot 2021$

\title{
ECOSYSTEMS
}

\section{Population structure and spatial distribution of tucumã-do-pará (Astrocaryum vulgare Mart.) in Salvaterra, Marajó island, Pará}

\author{
GABRIELE N. FURTADO, PRISCILA S.M. SARMENTO \& FLÁVIA C.A. LUCAS
}

\begin{abstract}
Astrocaryum vulgare Mart. is a palm tree that tolerates multiple environmental conditions, with complex development characteristics. The objective is to understand the population structure, the spatial distribution of this species in different environments and the effect of environmental gradients on its occurrence on Marajó Island, Pará. The hypothesis is that the population density of the species, as well as the spatial distribution, depends on the environment in which it is inserted. The study was carried out in 11 communities of residents of five different physiognomies, in which all individuals belonging to 42 sample units were mapped, measured and were categorized in height classes for further analysis. The results showed an abundance of juvenile individuals and a spatial distribution grouped across all physiognomies. The evidence points to a growing population, probably influenced by anthropic actions. Variables such as vegetation index of normalized difference, slope and distance from rivers were shown to be linked to the development of morphological characteristics. Finally, the occurrence of this species in physiognomies may be linked to the land use system, as it contributes to the creation of favorable environments for its development and, although differently, it has shown a high degree of adaptation to atypicals.
\end{abstract}

Key words: Amazon, biodiversity, conservation, Marajó, socioeconomics.

\section{INTRODUCTION}

Palm trees dominate the Amazon landscape. This is due to the fact that they have the capacity to tolerate multiple environmental conditions in large territories, in addition to being intentionally cultivated by contemporary societies (Pitman et al. 2013, Balée 2013, Boivin et al. 2016). Its occurrence is strongly linked to the seasonality of rainfall and river floods, growing in dynamic and heterogeneous environments, suitable for diversification (Balslev et al. 2015). A typical palm of this landscape is Astrocaryum vulgare Mart.), Known as tucumã-do-pará, which plays an important role in the structure and functioning of many ecosystems (Elias et al. 2015, Elias 2017), in addition to having a value invaluable cultural resource for Amazonian people, who use practically all parts of plants in a variety of applications, mainly in Marajó Island, Pará (dos Santos et al. 2015, Oliveira et al. 2018).

This species occurs spontaneously in different environments, whether in the form of clumps or solitary plants, and can easily sprout after fires (Cymerys et al. 2005, Guedes 2006, Zaninetti 2009), which are recurrent in Marajó. Due to the complexity of the characteristics of this species, further study of the population structure, that is, the development and biological characteristics of its individuals, allows us to understand their current interaction with the environment, diagnose the occurrence of 
previous disorders and, in some cases, cases, make inferences from projections of future scenarios (Silva et al. 2009, Gatsuk et al. 1980).

Hutchings (1997) states that the size structure of a population is determined by factors that influence variations in size between individuals, such as differences in seed size, germination time of each seed in relation to its neighbors, growth rate of each plant (which depends on ecological and genetic factors), distance from each plant to its closest neighbor (competition), and the pattern of behavior of herbivores. As population density changes over time and space, no population has a static structure, the perception of a population depends on where and when it is observed, as these aspects determine specific structural features of the population (Ricklefs 1996).

Parallel to this theme, there is the study of the spatial distribution of trees that is related to ecological processes that act throughout life and reveals how individuals organize themselves (when seedlings, juveniles and adults) in the environment and within a population (Peroni \& Hernándes 2011). It is a key issue for studies of forest ecology that allows analyzing the structure of the community itself, knowing important ecological processes, such as competition, herbivory and seed dispersal (Barot et al. 1999, Schwarz et al. 2003). In this approach, the combination of biotic and abiotic factors along the horizontal plane can assist in understanding the spatial dependence of tree species and their distribution patterns (Pereira et al. 2006, Silva et al. 2009), in which, establishing the relative importance of the factors that define the composition and distribution of species is a challenge, where ecological entities, such as individuals, populations, species and communities, exhibit complex patterns of variation in space (Dray et al. 2012, Layerghifard et al. 2015).
Thus, the objective of the present work was to understand the population structure and the spatial distribution of tucumã-do-pará in different environments, as well as the effect of environmental gradients on its occurrence on Marajó Island, Pará. The hypothesis is that the density population typical of the species, as well as the spatial distribution, depends on the environment in which it is inserted, as suggested by Nicotra et al. (2010) and Mota et al. (2014).

\section{MATERIALS AND METHODS}

\section{Characterization of the study area}

The study was conducted in the communities of Deus Ajude, Providência, Joanes, Maruacá, Jubim, Caldeirão, Ilha grande, Cururú Grande, Água boa and Passagem grande, located in the municipality of Salvaterra, in the Marajó Mesoregion (latitude $00^{\circ} 45^{\prime} 21^{\prime \prime}$ and longitude $48^{\circ} 45^{\prime} 54^{\prime \prime}$ from Greenwich) (Figure 1). Currently, the territorial area of Salvaterra corresponds to $918.563 \mathrm{~km}^{2}$ (IBGE 2018). Marajó Island is characterized by a hot and humid tropical climate, with an average annual temperature of $27^{\circ} \mathrm{C}$. The island's climate, according to Köppen classification, has two climatic units: humid tropical climate (Af), with an average rainfall greater than or equal to $60 \mathrm{~mm}$ in the driest month; and humid tropical monsoon climate (Am), characterized by excessive precipitation for a few months, compensating for the occurrence of one or two months of low rainfall.

Five different physiognomies were identified in the communities visited, according to the vegetation typology of Lisboa (2012) and Machado et al. (2008), with the following descriptions: Backyard (B), areas where biodiversity and the culture of local communities are preserved, considered productive areas in which the floristic composition is influenced by cultural tradition; Savannah Park (SP), characterized 

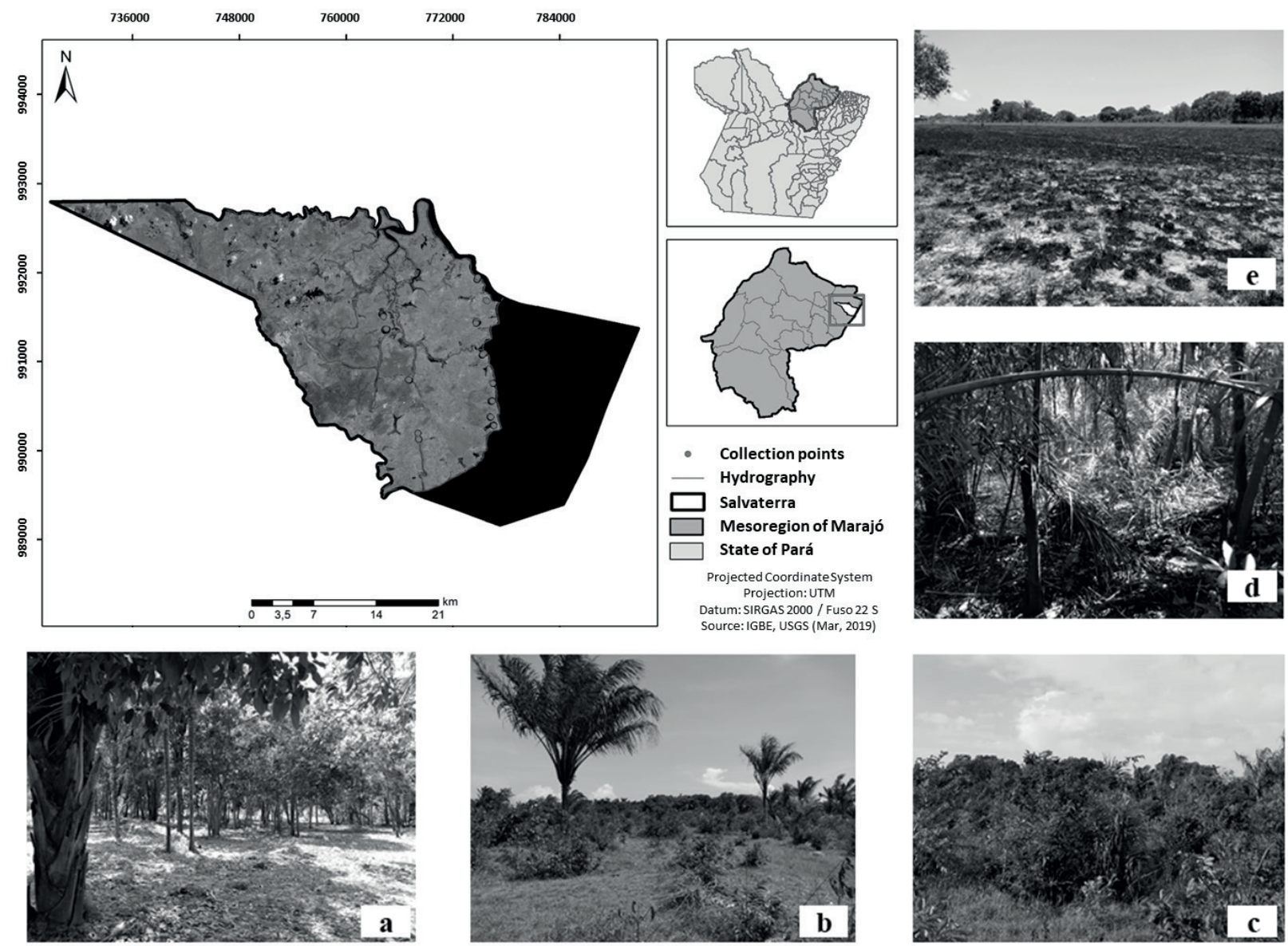

Figure 1. Location of the communities in which tucumã-do-pará individuals were mapped in Salvaterra, Pará, Brazil, and physiognomies of occurrence: a) Backyard; b) Savannah Park; c) Transition between Savannah grassland and Savannah Park; d) Secondary Forest; e) Savannah grassland.

by small, sparse trees, interspersed with shrubs and herbaceous vegetation, with part of the vegetation modified by agricultural and livestock activities; transition between Savannah grassland and Savannah Park (G/SP); Secondary Forest (SF), resulting from human interference but in advanced stages of succession, with plants of predominantly arboreal-shrubby habit, with the presence of lianas, herbs, epiphytes and hemiparasites; and Savannah grassland $(\mathrm{G})$, characterized by herbaceous-subshrub vegetation, dominated by legumes, Poaceae and tree species (Figure 1).

\section{Sampling and data analysis}

Field collections took place in September 2018, with the establishment of 42 plots (total survey area: 9.1 hectares). All results are estimated and presented per plot (sampling unit). All tucumãdo-pará individuals within each plot were counted, georeferenced, and had the following parameters measured: diameter at breast height (DBH) at $1.30 \mathrm{~m}$ from the ground, trunk height, and tree top height (from the base to the apical point of the leaf); individuals without exposed trunks also had the height estimated (Guilherme \& Oliveira 2011). The distance between all plots ranged from 250 to 26.000 meters. 
For the analysis of the population structure, individuals were considered. For the analysis of the population structure, individuals were classified into four heights, as in Guilherme \& Oliveira (2011), with minor adaptations: Class I (0.1-1.0 m), II (1.1-3.0 m), III ( $\geq 3.0 \mathrm{~m})$, and IV ( $\geq 2.0$ $\mathrm{m})$. Classes I, II and III included both seedlings with entire leaves and juveniles with divided leaves, but with non-exposed trunks and without signs of reproduction, thus considered juveniles. Class IV included plants with well-developed and reproductive trunks, presenting inflorescences or signs of reproduction, assumed to be adults.

The Morisita's index of dispersion (Id) was used to evaluate the spatial distribution pattern of the species in each physiognomy (Brower \& Zar 1984). In this index, Id values smaller than 1.0 indicate the absence of clustering; values equal to 1.0 indicate regular distribution; and values greater than 1.0 indicate clustering. The significance of the Morisita's index of dispersion $\left(I d^{1} 1\right)$ was tested using the $F$ test $(d f=n-1, p<$ 0.05) (Poole 1974).

The methodology of Gomes et al. (2016) was used to understand the influence of environmental gradients such as the distance of each plot from rivers $(4 m-3000 m)$, houses $(4 m-202 m)$ and roads $(8 m-103 m)$ on the occurrence of tucumã-do-pará. Measurements were made in a geographic information system (GIS) environment, based on the distance (in meters) of the centroid of each sampling unit in a straight line to each gradient.

Landsat 8 images corresponding to the collection months were used for the calculation of the Normalized Difference Vegetation Index (NDVI). In this calculation, normalized values vary between -1 and 1 ; values closer to 1 indicate greater vegetation cover, and values closer to -1, less remnant vegetation. For ground targets, the lower limit is approximately zero, and the upper limit, approximately 0.8 (Ponzoni et al. 2012).
Data from the Instituto Brasileiro de Geografia e Estatística (IBGE) of 2019 were used to survey information on geomorphology and slope. Slope was reclassified in terms of percentage for a better identification of the values found in the area, as follows: flat (0-2\%), smooth wavy (2-5\%), wavy (5-10\%), moderately wavy (10 - 15\%), strongly wavy (15-45\%), and mountainous (45-70\%). In turn, the database of the Brazilian Agricultural Research Corporation of the Brazilian territory (Embrapa) of 2014 was used for the pedological analyses. The analyses were performed using the ArcGIS software version 10.5 .

Analysis of variance (ANOVA) followed by Tukey's post-hoc test was used to detect differences between physiognomies, after evaluating the normality and homoscedasticity of the data. The plot was used as a sample unit. Biotic variables (density of juveniles and adults, DBH, trunk height, tree top height, and total height) were modeled as response variables in mixed linear models, using metrics corresponding to the distance of plots to houses, rivers and roads, as well as to the slope of the terrain, different types of soils, and different geomorphologies. Phytophysiognomy was treated as a random effect. The predictor variables were all dimensioned before the analysis. All modeling procedures were performed using the 'Imer' function of the Ime4 package (Bates et al. 2014).

Global mixed effects models were built for each response variable using the 'dredge' function (MuMIn package, Bartón 2015) to select models from all possible combinations, which explained more parsimoniously the data. The Akaike Information Criterion (AIC) was used to select the best models (Symonds \& Moussalli 2011), and all models with $\triangle A I C$ lower than 2 were considered equally parsimonious. After selecting the models, the average values and standard 
errors of the parameters were calculated using the 'model.avg' function of the MuMIn package, and the likelihood ratio tests evaluated the significance of each parameter estimated in the average model. All analyses were performed in the R environment (R Core Team 2018).

\section{RESULTS AND DISCUSSION}

\section{Population structure and size class distribution}

1684 individuals were found in the 9.1 ha mapped. These were distributed in classes of size that ranged from seedlings to adults over $2.0 \mathrm{~m}$ in height, showing that it is a population that is continuously developing in the areas of field (C), transition between field and park savannah (C / SP), savannah park (SP), secondary forest
(MS) and in backyards (Q). The highest relative density in the four size classes was higher in secondary forests, followed by backyards (Figure 2).

The size class $0.1-1.0 \mathrm{~m}$ was the least represented in all physiognomies. Individuals of this class may have originated from the regrowth of adult plants after cutting or fire, for example, or from the seed bank. Scariot (2000) mentions that seedlings correspond to the life stage most affected by forest fragmentation and disturbances. According to ethnobotanical surveys in Marajó Island, such as that of Rocha et al. (2014), the use of "óleo de bicho do tucumã" (lit. tucumã worm oil) is a cultural practice of great relevance. This substance is obtained through the collection of seeds attacked by larvae of Speciomerus ruficornis Germar., and this practice naturally reduces the seed bank

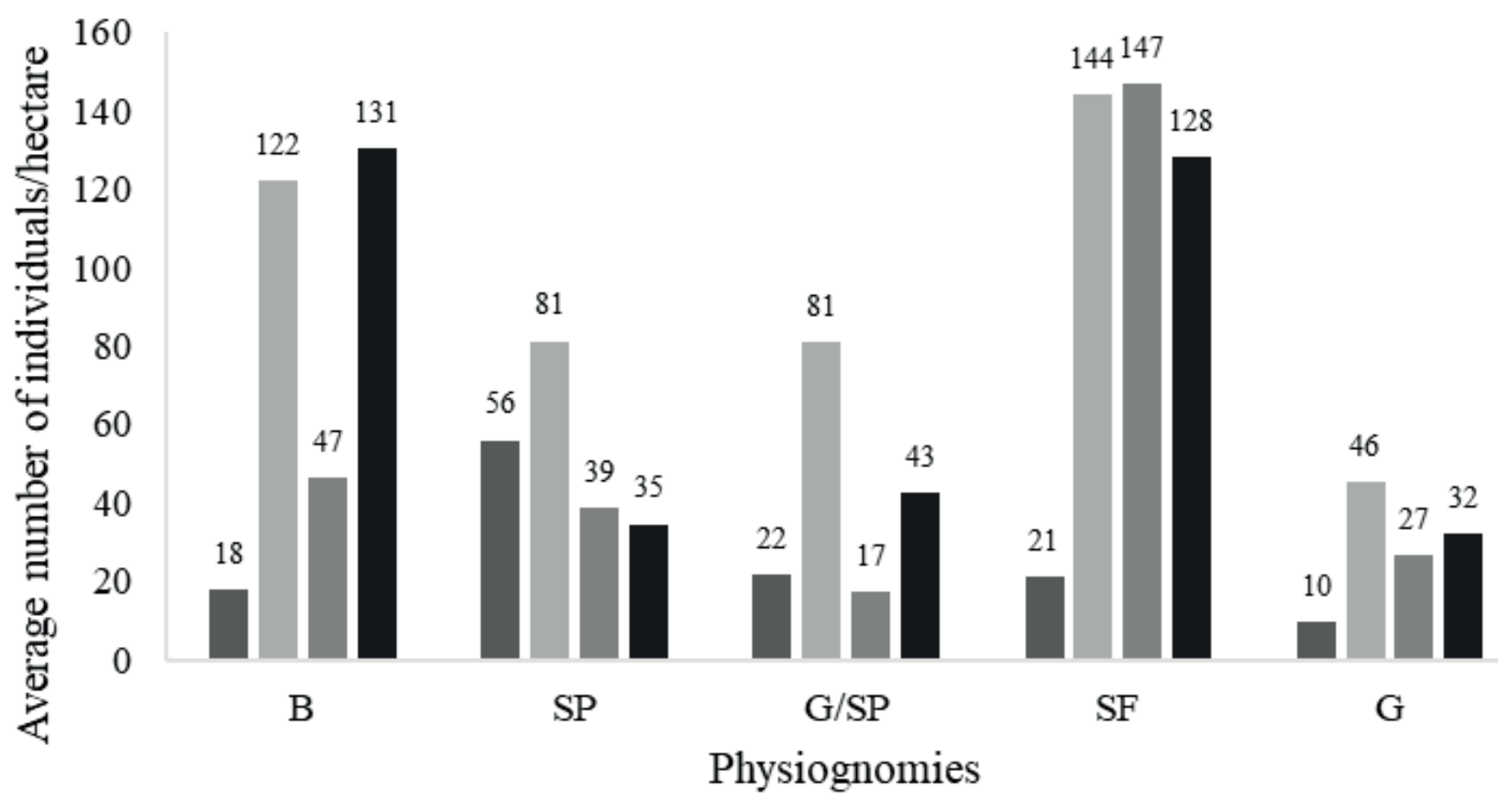

$\square \mathrm{C}-\mathrm{I}(0,1-1,0 \mathrm{~m}) \quad \square \mathrm{C}$-II $(1,1-3,0 \mathrm{~m}) \quad \square \mathrm{C}-\mathrm{III}(\geq 3,0 \mathrm{~m}) \quad \square \mathrm{C}-\mathrm{IV}(\geq 2,0 \mathrm{~m})$

Figure 2. Average number of individuals/hectare found in the height classes I $(0.1-1.0 \mathrm{~m})$, II (1.1 - 3.0m), III ( $\geq 3.0 \mathrm{~m})$ and IV ( $\geq 2.0 \mathrm{~m})$ for the physiognomies of Backyard (B), Savannah Park (SP), transition between Savannah grassland and Savannah Park (G/SP), Secondary Forest (SF), and Savannah grassland (G). 
of the palm tree. The use of fire in agriculture is typical in Marajó Island and widely observed in G, G/SP and SP areas (Pereira et al. 2006, Garcia et al. 2014). Another explanation is the variation in the height of juveniles of class I - 1.1 to $3.0 \mathrm{~m}$ and $I I-\geq 3.0 \mathrm{~m}$, which probably developed or germinated in different periods. Particularly class II individuals stood out, being the most expressive in all physiognomies. Furthermore, individuals taller than $1.0 \mathrm{~m}$ and with nonexposed stems are less susceptible to predation because they exhibit a greater number of large leaves (Hechenberger \& Ferreira 2017).

The density of adult individuals was similar in all physiognomies, somewhat higher in B areas. The maintenance of adult individuals in productive areas, strongly influenced by the cultural tradition of the residents (Chagas et al. 2014), demonstrates the knowledge of these people about the use of natural resources. In the work of Gonçalves \& Lucas (2017), the occurrence of species such as tucumã-do-pará in these areas was usually associated with food and commercial purposes. It is worth mentioning that few juveniles are naturally found in backyards because sprouts are usually cut off (Weinstein \& Moegenburg 2004). As reported by Ferreira \& Sablayrolles (2009), backyards are areas used as for leisure and socialization spaces, promoting well-being through the acknowledgment (shade) and the landscape created by tree species (Siviero et al. 2011).

It is emphasized that Savannah grassland areas exhibited the lowest abundance of tucumã-do-pará. According to Cymerys et al. (2005), these areas should have the largest number of individuals due to the species' ability to regrowth after fires, a common activity that favors regeneration through tillers. Moreover, these are open areas with high luminosity, favorable to pioneer species such as tucumãdo-pará. This shows that, despite the family based character of seed collection aimed at self-consumption (Pereira et al. 2006), when analyzed on a local scale, this activity may be leading to the decrease of this species in this type of physiognomy.

The higher density of individuals found in secondary forest showed the ability of this species to remain in the following successional stages, demonstrating that the environmental filters to which it is subjected are not sufficient to exclude it. Environmental filters can limit or hamper the succession process of secondary forests, directly or indirectly interacting with the species abundance patterns. Thus, this finding can be explained by the fact that palm trees exhibit ecophysiological adaptations to occupy the specific environmental conditions of various physiognomies, as highlighted by Wandekoken (2018).

Figure 3 shows the number of individuals found in all plots, which were distributed in their respective height classes. Thus, considering the total number of individuals in the study area, there was a predominance of height class II; juveniles (classes I, II and III) represented 65.7\% of the total, while adults (C-IV) corresponded to $34.3 \%$.

The population structure was not as expected; it followed a J-inverted or negative exponential pattern in which there was a predominance of young individuals (smaller size) and a lower representation of larger classes (larger size). This condition is interpreted as an indicator of forest regeneration and can result in both stability and population growth (Bambolim \& Wojciechowski 2017). The population structure was not as expected; followed a J-inverted or negative exponential pattern in which there was a predominance of young individuals (smaller size) and less representation of larger classes (larger size). This condition is interpreted as an indicator of forest regeneration and can result 


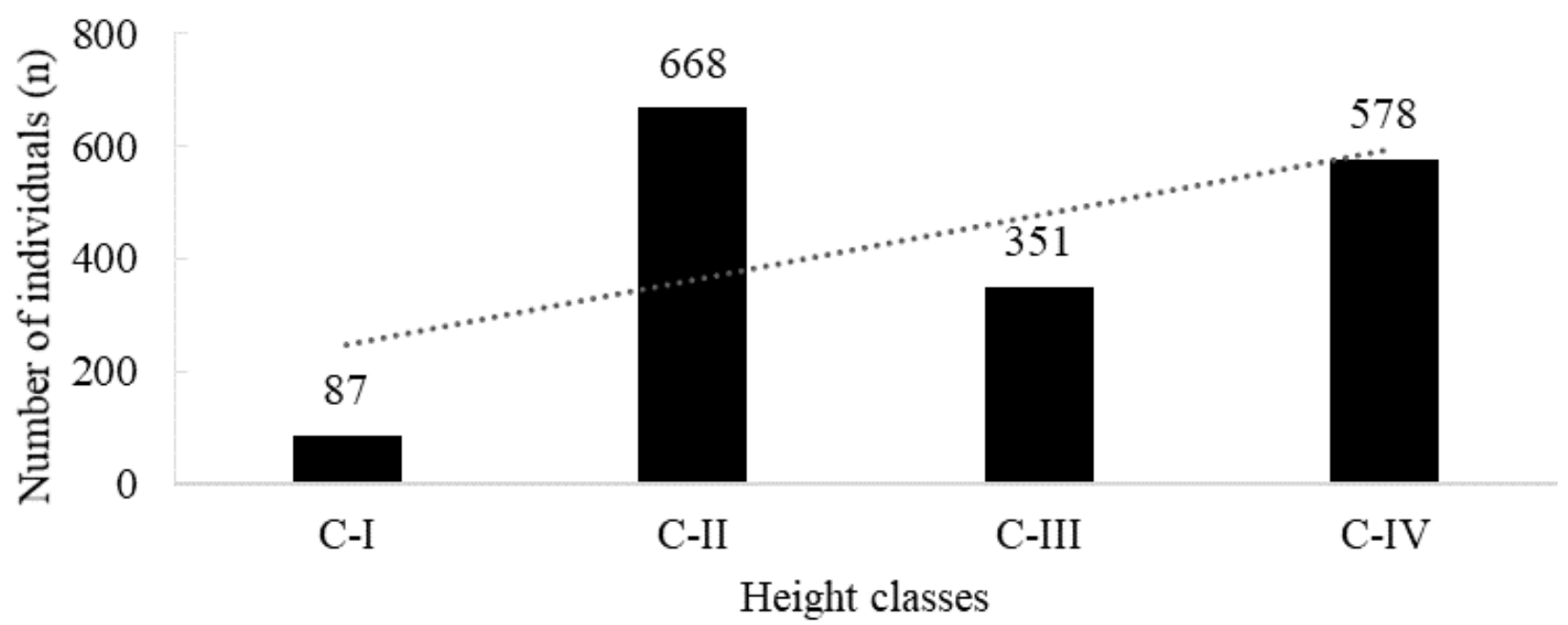

Figure 3. Number of individuals of tucumã-do-pará by height class in the physiognomies of Backyard (B), Savannah Park (SP), transition between Savannah grassland and Savannah Park (G/SP), Secondary Forest (SF), and Savannah grassland (G).

in population stability and growth (Bambolim \& Wojciechowski 2017). However, Condit et al. (1998) points out that it is complicated to make inferences about future trends in populations using point data of the size structure, due to differences in growth rates between size classes. Virillo et al. (2011) in their work point out that size distribution density histograms are not good indicators of future trends in the population number for the species, which makes it necessary to use the results found in this research with other results in which, together, contribute with the greatest clarity and the closest to reality about population growth and the future of this species. Abundance of individuals of the different height classes was observed, mainly of those $1.1 \mathrm{~m}$ tall or taller.

Statistically significant variation between the physiognomies was found in all biotic variables except trunk height (Figure 4). The largest DBH values were found in SP, as well as the lowest trunk height, tree top height, and total height values.

The typical growth pattern of palm trees, determined by the absence of secondary growth, allows these plants to reach higher heights at smaller trunk diameters than other tree species (Ma et al. 2015, Fisch \& Gomes 2011). This is in line with our results of greater variation in height than in DBH for all individuals; however, it is clear that the population of tucumã-dopará in Salvaterra has not yet reached the height described in the literature, as mentioned in the works of Menezes et al. (2012) and Cymerys (2005), who report a variation from 10 to $15 \mathrm{~m}$. We can conclude, thus that populations in Salvaterra are relatively young.

According to Fisch (1999), the concentration of the largest number of trunks in a single height and DBH class indicates very mature plant populations in advanced stages of reproduction. This was not observed in the populations of tucumã-do-pará studied in Salvaterra: a considerable abundance of individuals was observed in all classes.

Concerning the spatial distribution pattern of tucumã-do-pará, significantly clustered patterns (Id > 1.0) were found in all physiognomies. When analyzed by size classes, juveniles had significantly higher cluster values, while adults in Backyard and Savannah Park areas were clustered but with lower indices. Similarly, 

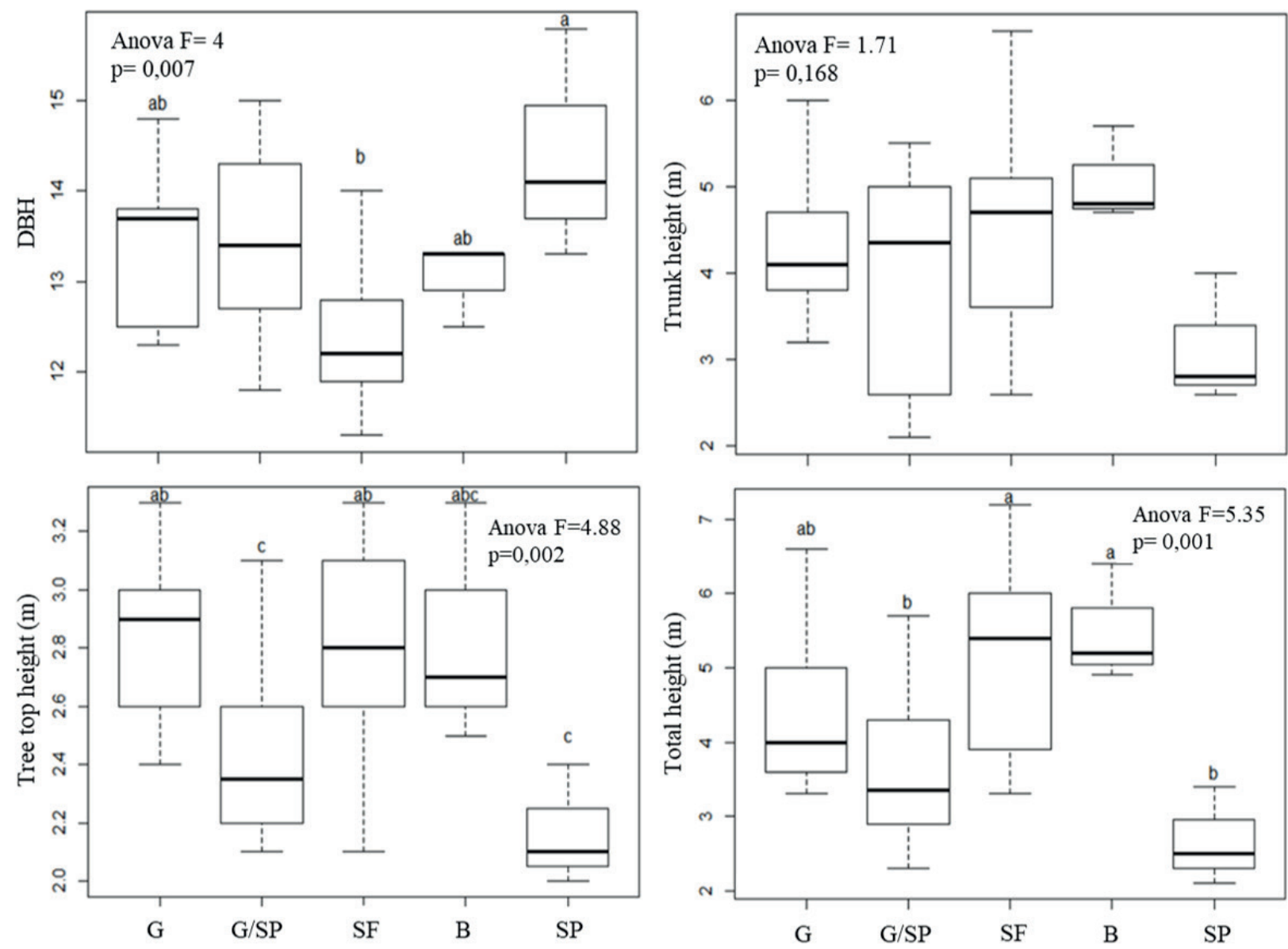

Figure 4. ANOVA (F) of biotic variables compared between the different physiognomies. $p$ indicates the level of significance and different letters indicate significant differences between physiognomies according to Tukey's post-hoc test $(p<0.05)$.

to the influence on population structure, the type of reproduction seems to influence the occupation and distribution pattern of the species (Supplementary Material - Table SI). As observed by Oliveira \& Rios (2014), the vegetative reproduction observed in some palm trees, such as tucumã, causes the aggregation of individuals through regrowth, stimulated mainly by fire (Voeks 1988, Cymerys et al. 2005), which is recognized in Pilon's work (2019) as a strategy of regeneration.

Another factor that contributes to the aggregation of individuals is that these species commonly present a long fruiting phase, barochoric dispersion of the fruits and production of a large number of seeds (Janze 1976). Thus, as the tucumã-do-pará produces countless fruits, a large part of this resource is naturally deposited in the soil by abscission (Pereira \& Mantovani 2001), favoring germination. Therefore, the probability of finding individuals closer to each other and, therefore, populations with a grouped spatial pattern, is greater than that of species that reproduce preferentially by crossing (Barbour et al. 1987).

Another cause concerns the slow germination of this species, which in a way imposes a temporary restriction on recruitment, influencing the higher frequency of the young stadium (Lorenzi et al. 2010). Oliveira \& Rios 
(2014), in accordance with Freckleton et al. (2003) mentions that mortality is inversely proportional to growth, with the plant being affected by density dependence. Therefore, as the species invests in resources in the production of fruits and seeds, a seedling bank is formed to compensate for mortality and guarantee the survival of a number of individuals that will maintain population stability (Fisch 1999). The grouped pattern of tucumã-do-pará individuals was observed in all physiognomies, despite the differences between them and the existence of anthropic interferences.

NDVI, which shows the condition of vegetation, or vegetation cover, is an important variable for understanding the variation of the population structure and the spatial distribution of the tucumã-do-pará (Table I). The density of juvenile individuals, trunk height values, and tree top height values increase with the complexity of the landscape (higher NDVI values). On the other hand, DBH decreases with the increase in NDVI values, which is explained by the need for energy investment to reach the highest part of the vegetation. It is noteworthy that tucumãdo-pará shows rapid adaptation to open areas, whether natural or man-made; however, the highest NDVI values indicate that environmental heterogeneity, that is, the adjacent vegetation, directly influences the occurrence of this species. This is demonstrated by the fact that the higher density of juveniles occurred in more closed areas, such as secondary forests. This suggests that secondary forests may provide a shelter

Table I. Mean coefficients (standard errors) of the model predicting the characteristics of tucumã-do-pará populations according to abiotic variables. Legend: DH - distance from houses, DRO - distance from roads, DRI distance from rivers, SL - slope, PEDOL - pedology, GEOM - geomorphology, and NDVI.

\begin{tabular}{|c|c|c|c|c|c|c|c|c|}
\hline Variables & Intercept & DH & DRO & DRI & SL & PEDOL & GEOM & NDVI \\
\hline $\begin{array}{c}\text { Density } \\
\text { adults (ha) }\end{array}$ & $\begin{array}{c}83.31 \\
(27.66) \\
\star \star\end{array}$ & $\begin{array}{l}-11.83 \\
(14.01)\end{array}$ & - & - & - & - & - & $\begin{array}{l}19.22 \\
(0.26)\end{array}$ \\
\hline $\begin{array}{l}\text { Density } \\
\text { juveniles } \\
\text { (ha) }\end{array}$ & $\begin{array}{c}152.13 \\
(28.95)^{* * *}\end{array}$ & - & $\begin{array}{lll}- & \\
\end{array}$ & - & - & - & $\begin{array}{c}37.95 \\
(32.86)\end{array}$ & $\begin{array}{c}37.95 \\
(32.86) \\
* *\end{array}$ \\
\hline $\mathrm{DBH}$ & $\begin{array}{c}13.50 \\
(0.126) * * *\end{array}$ & $\begin{array}{c}0.063 \\
(0.126)\end{array}$ & - & $\begin{array}{c}0.296 \\
(0.128) \\
*\end{array}$ & - & - & & $\begin{array}{c}-0.524 \\
(0.131) \\
* * *\end{array}$ \\
\hline $\begin{array}{l}\text { Trunk } \\
\text { height }\end{array}$ & $\begin{array}{c}4.23 \\
(0.150) \\
* * *\end{array}$ & - & - & - & $\begin{array}{c}-0.518 \\
(0.159) \\
* *\end{array}$ & $\begin{array}{c}0.187 \\
(0.151)\end{array}$ & - & $\begin{array}{c}0.320 \\
(0.153) \\
*\end{array}$ \\
\hline $\begin{array}{l}\text { Tree top } \\
\text { height }\end{array}$ & $\begin{array}{c}2.65 \\
(0.43) \\
* * *\end{array}$ & $\begin{array}{c}-0.038 \\
(0.056) \\
*\end{array}$ & - & - & $\begin{array}{c}-0.154 \\
(0.054) \\
* *\end{array}$ & - & $\begin{array}{c}-0.083 \\
(0.077) \\
*\end{array}$ & $\begin{array}{c}0.198 \\
(0.056) \\
* * *\end{array}$ \\
\hline $\begin{array}{l}\text { Total } \\
\text { height }\end{array}$ & $\begin{array}{l}4.03 \\
(0.46) \\
\star \star \star\end{array}$ & $\begin{array}{l}-0.274 \\
(0.171)\end{array}$ & $\begin{array}{l}-0.222 \\
(0.154)\end{array}$ & - & $\begin{array}{l}-0.191 \\
(0.172)\end{array}$ & $\begin{array}{c}0.696 \\
(0.203) \\
* *\end{array}$ & - & $\begin{array}{c}0.320 \\
(0.153)\end{array}$ \\
\hline
\end{tabular}

Significance levels: ${ }^{*} 0.01<p \leq 0.05,{ }^{* *} 0.001<p \leq 0.01,{ }^{* * *} 0.0001<p \leq 0.001$. 
for palm species and, consequently, for the fauna that depends on the resources of these species. Yet, according to Sternbergetal (2007), biodiversity is a potential key factor influencing the emergence and feedbacks of species in the environment.

The slope was negatively correlated with trunk height and tree top height; more wavy terrains were associated with lower heights. Tree top height values were also influenced by the distance to houses (negative correlation) and variation in geomorphology. $\mathrm{DBH}$ values increased with increasing distance from rivers (Table SII).

Results like these corroborate the studies mentioned by Whittaker (1956), Jardim et al. (2007), Arasato \& Amaral (2013) and Santos et al. (2018) in which environmental variables and gradients directly influence the patterns and occurrence of individuals. Bjorholm et al. (2006) and Eiserhardt et al. (2011) also highlight that the distribution and diversity of palm trees is related to water availability (air and soil), temperature and topography. Ruokolainen \& Vormisto (2000) found that palm trees with the capacity to survive in different edaphic conditions have a larger area of distribution.

The vegetation in Marajó presents not only relationships with relief and soil characteristics, but also with other physiographic, paleogeographic and anthropic elements (Furtado et al. 2009). In this context, Levis et al. (2012), Shepard \& Ramirez (2011) and Stahl (2015) highlight that although many physiognomies in Marajó Island appear to be natural, they are under influences from varied sources and undergo constant changes in terms of plant density, and the degree of modification of the vegetation surrounding villages/communities decreases as the distance from these settlements increases. In these anthropogenic physiognomies, the concentration of useful species is detectable in distances up to $40 \mathrm{~km}$ from main and even smaller rivers (Levis et al. 2012), as observed in the population of tucumã-do-pará.

\section{CONCLUSION}

The results of this study showed that the population of tucumã-do-pará showed typical density of the species, with abundance of juvenile individuals and clustered spatial distribution pattern in all the studied physiognomies. They also revealed that the populations suffer direct anthropic influence in the different environments where they occur. Alterations of the landscape are evident in all the study areas and they may be shaping the population distribution in the municipality of Salvaterra. For example, grassland areas had lower densities of individuals, and secondary forests, larger densities, indicating that the richness of adjacent species may be favoring the establishment of this species, becoming a refuge. The results also revealed that the population is still growing, probably due to the use of parts of this species for various purposes. Finally, the occurrence of this species in the studied physiognomies may be linked to the land use system, as it contributes to the creation of favorable environments for its development and, even differently, it has shown a high degree of adaptation to non so typical.

\section{REFERENCES}

ARASATO LS \& AMARAL S. 2013. Geoprocessamento e Biodiversidade: contribuições para a modelagem da distribuição de palmeiras Amazônicas. Anais XVI Simpósio Brasileiro de Sensoriamento Remoto - SBSR, Foz do Iguaçu, PR, Brasil, 13 a 18 de abril, INPE.

BALÉE W. 2013. Cultural Forests of the Amazon: a Historical Ecology of People and their Landscapes. Tuscaloosa, AL: The University of Alabama Press. 
BALSLEV H, PEDERSEN D, NAVARRETE H \& PINTAUD J. 2015. diversidad y abundancia de palmas. In: Balslev $H$, Macía M and Navarrete $H$ (Eds), Cosecha de palmas en el noroeste de Suramérica: bases científicas para su manejo y conservación. Quito, Pontificia Universidad Católica del Ecuador, p. 13-25.

BAMBOLIM A \& WOJCIECHOWSKI JC. 2017. Composição florística e fitossociológica de um remanescente de floresta ombrófila mista. Rev Agric Neotrop 4(1): 28-35. Disponivel em: <http://periodicosonline.uems.br/index. php/agrineo/article/view/1173>. Acesso em: 06 mar 2020.

BARBOUR MG, BURK JH \& PITTS WD. 1987. Terrestrial Plant Ecology. 2.ed. Califórnia: Benjamim/Cummings.

BAROT S, GIGNOUX J \& MENAUT JC. 1999. Demography of a savanna palm tree: predictions from comprehensive spatial pattern analyses. Ecology Oxford 80: 1987-2005.

BARTÓN K. 2015. MuMIn R package version 1.13.4. (http:// cran.rproject.org/web/packages/MuMIn/MuMIn.pdf).

BATES D, MULLEN KM, NASH JC \& VARADHAN R. 2014. Minqa: Derivative-Free Optimization Algorithms by Quadratic Approximation. R package version 1.2.4, URL <http:// CRAN. R-project.org/package $=$ minqa $>$.

BJORHOLM S, SVENNING JC, BAKER WJ, SKOV F \& BALSLEV H. 2006. Historical legacies in the geographical diversity patterns of New World palm (Arecaceae) subfamilies. Bot J Linn Soc 151(1): 113-125.

BOIVIN NL, ZEDER MA, FULLE DQ, CROWTHER A, LARSONG G, ERLANDSON JM, DENHAM T \& PETRAGLIA MD. 2016. Ecological consequences of human niche construction: examining long-term anthropogenic shaping of global species distributions. Proc Natl Acad Sci USA 113: 6388-6396.

BROWER JE \& ZAR JH. 1984. Field and laboratory methods for general ecology. 2 ed., Dubuque: Wm. C. Brown, 288 p.

CHAGAS JCN, FRAXE TJP, ELIAS MEA, CASTRO AP \& VASQUES MS. 2014. Os sistemas produtivos de plantas medicinais, aromáticas e condimentares nas comunidades São Francisco, Careiro da Várzea e Santa Luzia do Baixio em Iranduba no Amazonas. RBA 9(1): 111-121.

CYMERYS M, FERNANDES NMP \& RIGAMONTE-AZEVEDO OC. 2005. Buriti: Maurita flexuosa. In: Shanley P and Medina G. Frutíferas e Plantas Úteis na Vida Amazônica. Centro para Pesquisa Florestal Internacional (CIFOR) e Instituto Homem e Meio Ambiente da Amazônia (IMAZON), Belém, $300 \mathrm{p}$.

DOS SANTOS MDFG, MAMEDE RVS, RUFINO MDSM, DE BRITO ES \& ALVES RE. 2015. Amazonian Native Palm Fruits as Sources of Antioxidant Bioactive Compounds. Antioxidants 4(3): 591-602.

DRAY S ET AL. 2012. Community ecology in the age of multivariate multiscale spatial analysis. Ecological monographs. Lawrence 82: 257-275.

EISERHARDT WL, SVENNING JC, KISSLING WD \& BALSLEV H. 2011. Geographical ecology of the palms (Arecaceae): Determinants of diversity and distributions across spatial scales. Ann Bot 108: 1391-1416.

ELIAS GA. 2017. Palmeiras (Arecaceae) em Santa Catarina, Sul do Brasil. $191 \mathrm{f}$. Tese (Doutorado) - Universidade do Extremo Sul Catarinense, Programa de Pós-Graduação em Ciências Ambientais, Criciúma, SC.

ELIAS GA, CORRÊA PF, ZANETTE VC \& SANTOS R. 2015. Arecaceae: análise bibliométrica das espécies nativas do estado de Santa Catarina, Brasil. Ciênc Nat 37(1): 85-92.

FERREIRA TB \& SABLAYROLLES MGP. 2009. Quintais agroflorestais como fontes de saúde: plantas medicinais na comunidade de Vila Franca, Reserva Extrativista Tapajós-Arapiuns, Pará. RBA 4(2): 3159-3162.

FISCH STV. 1999. Dinâmica de Euterpe edulis Mart. na Floresta Ombrófila Densa Atlântica em Pindamonhangaba - SP. Tese (Doutorado em Ecologia) - Universidade de São Paulo, São Paulo.

FISCH STV \& GOMES EPC. 2011. Métodos de amostragem de palmeiras (Arecaceae) e estudo de caso na restinga de Ubatuba, Estado de São Paulo, Brasil. Editora UFV, 97 p.

FRECKLETON RP, SILVA MATOS DM, BOVI MLA \& WATKINSON AR. 2003. Predicting the impacts of harvesting using structured population models: the importance of density-dependence and timing of harvest for a tropical palm tree. J Appl Ecol 40: 846-858.

FURTADO AMM, FRANÇA CF \& PIMENTEL MAS. 2009. relações relevo-solo-vegetação da ilha de Marajó-Pa. In: XIII Simpósio Brasileiro De Geografia Física Aplicada, Minas Gerais. Anais. Minas Gerais: UFV, p. 1-11.

GARCIA ET, MARTINS ACC \& FAGUNDES DN. 2014. Diversidade florística de briófitas da Reserva Ecológica Do Bacurizal, Salvaterra, Ilha De Marajó, Pará, Brasil. Enciclopédia Biosfera, centro Científico Conhecer - Goiânia 10(19): 2168.

GATSUK LE, SMIRNOVA OV, VORONTZOVA LB \& ZHUKOVA LA. 1980. Age states of plants of various growth forms: a review. J Ecol 68: 675-696.

GOMES JP, CONDÉ TM, SANTOS RL, DIONISIO LFS, DUARTE OR, MIRANDA DLC \& SILVA F. 2016. Efeitos de gradientes ambientais na fitossociologia de assembleias de palmeiras no sudeste de Roraima, Brasil. Nativa 4: 317-327. 
GONÇALVES JP \& LUCAS FCA. 2017. Agrobiodiversidade e etnoconhecimento em quintais de Abaetetuba, Pará, Brasil. R Bras Bioci 15(3): 119-134.

GUEDES MM. 2006. Estudo da extração de óleo da polpa de tucumã por CO2 supercrítico. 80 f. Dissertação (Mestrado em Ciência e Tecnologia de Alimentos). Universidade Federal do Pará, Bélem. (Unpublished data).

GUILHERME FAG \& OLIVEIRA AS. 2011. Estrutura populacional de Butia purpurascens Glassman (Arecaceae) em duas áreas de Cerrado sensu stricto no estado de Goiás. Rev Biol Neotrop 7(1): 37-45.

HECHENBERGER S \& FERREIRA EJL. 2017. Comparação florística e fitossociológica entre comunidades de palmeiras de florestas secundárias e primária da Área de Proteção Ambiental 'Igarapé São Francisco', Acre, Brasil. Enciclopédia Biosfera, Centro Científico Conhecer - Goiânia 14(25): 334.

HUTCHINGS MJ. 1997. The structure of plant populations. In: Crawley MJ (Ed), Plant ecology. Oxford, Blackwell Scientific, p. 325-358.

IBGE. 2018. Instituto Brasileiro de Geografia e Estatística. Estados.

JANZE DH. 1976. Why bamboos take so long to flower. Ann Rev Ecol Syst 7: 347-391.

JARDIM MAG, SANTOS GC, MEDEIROS TDS \& FRANCEZ DC. 2007. Diversidade e estrutura de palmeiras em floresta de várzea do estuário amazônico. Amazônia: Ci \& Desenv 2(4): 67-84.

LAYERGHIFARD M, MARAKENKOV V \& PERES-NETO PR. 2010. Spatial and species compositional networks for inferring conectivity patterns in ecological communities. Glob Ecol Biogeogr 24: 386-398.

LEVIS C, SOUZA PF, SCHIETTI J, EMILIO T, PINTO JLPDV, CLEMENT CR \& COSTA FRC. 2012 Historical human footprint on modern tree species composition in the Purus-Madeira interfluve, central Amazonia. PLoS ONE 7: e48559.

LISBOA PLB. 2012. A terra dos Aruã: uma história ecológica do Marajó. Museu Paraense Emílio Goeldi. Belém, 482 p.

MA RY, ZHANG JL, CAVALERI MA, STERCK F, STRIJK JS \& CAO KF. 2015. Convergent Evolution towards High Net Carbon Gain Efficiency Contributes to the Shade Tolerance of Palms (Arecaceae). PLoS ONE 10(10): e0140384.

MACHADO AT, SANTILLI J \& MAGALHÃES RA. 2008. Agrobiodiversidade com enfoque agroecológico: implicações conceituais e jurídicas. Brasília, DF: Embrapa Informação Tecnológica: Embrapa Secretaria de Gestão e Estratégia, 98 p.

MENEZES AJEA, HOMMA AKO, OLIVEIRA MEC \& MATOS GB. 2012. Exploração do óleo de tucumã do Pará (Astrocaryum vulgare Mart.) na mesorregião da Itha do
Marajó-município de Soure- Pará. II Congresso Brasileiro de Recursos Genéticos; set 24-28; Belém, PA.

MOTA SLL, PEREIRA IM, MACHADO ELM, OLIVEIRA MLR, BRUZINGA JS, FARNEZI MMM \& MEIRA JUNIOR MS. 2014. Influências de afloramentos rochosos sobre a comunidade lenhosa no cerrado stricto sensu. Floresta e Ambient 21: 8-18.

NICOTRA AB ET AL. 2010. Plant, phenotypic plasticity in a changing climate. Trends in Plants Science, Oxford.

OLIVEIRA MSP \& RIOS SA. 2014. Potencial econômico de algumas palmeiras nativas da Amazônia. VI Encontro Amazônico de agrárias - ENAAG.

OLIVEIRA SF, NETO JPM \& SILVA KER. 2018. Uma revisão sobre a morfoanatomia e as propriedades farmacológicas das espécies Astrocaryum aculeatum Meyer e Astrocaryum vulgare Mart. Scientia Amazonia 7(3): CS18-CS28.

PEREIRA KJCP, LIMA BF, REIS RS \& VEASEY EA. 2006. Saber tradicional, agricultura e transformação da paisagem na Reserva de Desenvolvimento Sustentável Amanã, Amazonas. UAKARI 2(1): 9-26.

PEREIRA TS \& MANTOVANI W. 2001. Maturação e dispersão de Miconia cinnamomifolia (DC) Naud. na Reserva Biológica de Poço das Antas, município de Silva Jardim, RJ, Brasil. Acta Bot Bras 15(3): 335-348.

PERONI N \& HERNANDEZ MIM. 2011. Ecologia de populações e comunidades. Florianópolis: CCB/EAD/UFSC, 123 p.

PILON NAL. 2019. Efeitos de distúrbios naturais e da supressão do fogo na diversidade e estrutura do estrato herbáceo-arbustivo do Cerrado. Tese (Doutorado) - Universidade de Campinas, Instituto de Biologia. Campinas, SP: [s.n.].

PITMAN NCA, SILMAN MR \& TERBORGH JW. 2013. Oligarchies in Amazonian tree communities: A ten-year review. Ecography 36: 114-123.

PONZONI FJ, SHIMABUKURO YE \& KUPLICH TM. 2012. Sensoriamento Remoto da Vegetação. 2. Ed. Atualizada e ampliada - São Paulo: Oficina de textos.

POOLE RW. 1974. Introduction to quantitative ecology. Tokyo: Mc Graw-Hill, 532 p.

R CORE TEAM. 2018. R: A language and environment for statistical computing. R Foundation for Statistical Computing, Vienna, Austria. URL <https://www.R-project. $\operatorname{org} />$.

RICKLEFS RE. 1996. A economia da natureza. Guanabara Koogan, Rio de Janeiro.

ROCHA TT, TAVARES-MARTINS ACC, LUCAS FCA \& MARTINS RCC. 2014. Potencial terapêutico e composição química do óleo de bicho do tucumã (Astrocaryum vulgare Mart.) utilizado na medicina popular. Scientia Plena 10(11): 111001. 
RUOKOLAINEN K \& VORMISTO J. 2000. Ecology The most widespread Amazonian palms tend to be tall and habitat generalists. BAAE 1: 97-108.

SANTOS HG, JACOMINE PKT, ANJOS LHC, OLIVEIRA VA, LUMBRERAS JF, COELHO MR, ALMEIDA JA, ARAÚJO FILHO JC, OLIVEIRA JB \& CUNHA TJF. 2018. Sistema Brasileiro de Classificação de Solos. 5. ed. rev. e ampl. Brasília, DF: Embrapa. E-book: il. color. E-book, no formato ePub, convertido do livro impresso, $365 \mathrm{p}$.

SCARIOT AO. 2000. Seedling mortality by litterfall in Amazonian forest fragments. Biotropica 32(4): 662-669.

SHEPARD JR GH \& RAMIREZ H. 2011 'Made in Brazil': human dispersal of the Brazil nut (Bertholletia excelsa, Lecythidaceae) in ancient Amazonia. Econ Bot 65: 44-65.

SILVA MGCPC, MARTINI AMZ \& ARAÚJO QR. 2009. Estrutura populacional de Euterpe edulis Mart. no Sul da Bahia, Brasil. Revista Brasil Bot 32(2): 393-403.

SIVIERO A, DELUNARDO TA, HAVERROTH M, OLIVEIRA LC \& MENDONÇA MAS. 2011. Cultivo de Espécies Alimentares em Quintais Urbanos de Rio Branco, Acre, Brasil. Acta Bot Bras Belo Horizonte 25(3): 549-556.

STAHL PW. 2015. Interpreting interfluvial landscape transformations in the pre-Columbian Amazon. Holocene 25(10): 1598-1603.

STERNBERG LSL, TEH SY, EWE SML, MIRALLES-WILHELM F \& DEANGELIS DL. 2007. Competition between hardwood hammocks and mangroves. Ecosystems 10: 648-660.

SYMONDS MRE \& MOUSSALLI A. 2011. A brief guide to model selection, multimodel inference and model averaging in behavioural ecology using Akaike's information criterion. Behav Ecol Sociobiol 65(1): 13-21.

VOEKS RA. 1988. The Brazilian fiber belt: Harvest and management of Piassava palm (Attalea funifera Mart.). AEB 3: 254-271.

WANDEKOKEN DT. 2018. Distribuição espacial e diversidade funcional de palmeiras (Arecaceae) em florestas de restinga. Dissertação de Mestrado apresentada ao Programa de Pós-Graduação em Biologia Vegetal do Centro de Ciências Humanas e Naturais da Universidade Federal do Espírito Santo, 72 p. (Unpublished data).

WEINSTEIN S \& MOEGENBURGS. 2004. Açaí palm management in the Amazon Estuary: Course for conservation or passage to plantations. Conserv Soc 2: 314-346.

WHITTAKER RH. 1956. Vegetation of the Great Smoky Mountains. Ecol Monogr 26: 1-80.

ZANINETTI RA. 2009. Caracterização do óleo de frutos de tucumã (Astrocaryum aculeatum) para produção de biodiesel. Dissertação (Mestrado em Agronomia) Universidade Estadual Paulista "Julio de Mesquita Filho", Jaboticabal, 60 p. (Unpublished data).

\section{SUPPLEMENTARY MATERIAL}

\section{Table SI.}

Table SII.

\section{How to cite}

FURTADO GN, SARMENTO PSM \& LUCAS FCA. 2021. Population structure and spatial distribution of tucumã-do-pará (Astrocaryum vulgare Mart.) in Salvaterra, Marajó island, Pará. An Acad Bras Cienc 93: e20201186. DOI 10.1590/0001-3765202120201186.

Manuscript received on July 24, 2020;

accepted for publication on May 17, 2020

\section{GABRIELE N. FURTADO'}

https://orcid.org/0000-0002-6913-1848

\section{PRISCILA S.M. SARMENTO²}

https://orcid.org/0000-0002-5001-9573

\section{FLÁVIA C.A. LUCAS ${ }^{1}$}

https://orcid.org/0000-0002-0752-7206

${ }^{1}$ Programa de Pós-Graduação em Ciências Ambientais, Universidade do Estado do Pará, Centro de Ciências Naturais e Tecnologia, Travessa Dr. Enéas Pinheiro, 2626, Marco, 66095-015 Belém, PA, Brazil

${ }^{2}$ Instituto Tecnológico Vale, Desenvolvimento Sustentável, Rua Boa Ventura da Silva, 955, Nazaré, 66055-090 Belém, PA, Brazil

Correspondence to: Gabriele do Nascimento Furtado E-mail: gabriele.engflor@gmail.com

\section{Author contributions}

Gabriele do Nascimento Furtado: This work is the result of her master's project. Responsible for data collection, reference survey, elaboration of hypotheses and text writing.

Priscila S.M. Sarmento: she was co-advisor of the master's degree, responsible for the sample design of the research and statistical analysis of the data, and also helped in the drafting of the essay.

Flávia C.A. Lucas: she was the master's supervisor. She participated in the planning of the data survey, in addition to suggesting important contributions to the development of the article's writing and review.

\section{(cc) BY}

